\title{
2D magnetometric modeling of a basic-intermediate intrusion geometry: geophysical and geological approaches applied to the Limeira intrusion, Paraná Magmatic Province (SP, Brazil)
}

\author{
Lucas Martins Lino ${ }^{1 *}$, Francisco de Assis Cavallaro ${ }^{1,2}$, \\ Silvio Roberto de Farias Vlach ${ }^{1}$, Daniel Cunha Coelho ${ }^{1}$
}

\begin{abstract}
The Limeira Intrusion is an occurrence related to the Mesozoic continental flood basalts of Parana Magmatic Province, cropping out at the eastern Säo Paulo state. It is made up of basic-intermediate rocks with a great diversity of structures, textures and modal compositions, related to specific evolutionary process in a magma chamber. Previous geological and stratigraphic evidence suggests it has a lopolithic-like geometry rather than a conventional sill-like, assumed for most regional similar occurrences. 2D forward modeling of magnetometric data, based on available aerial and newly obtained ground data integrated with in situ rock magnetic susceptibility measurements, were used to test such hypothesis. The results, even considering intrinsic drawbacks of magnetometric theoretical models, are compatible with the geologic-based presumed intrusion geometry. The determination of intrusive bodies geometry is quite significant to explain their different emplacement mechanisms. In the case of Limeira Intrusion, the results suggest that the emplacement mechanism may occur, apparently, by inner-accretion of fresh magmatic pulses in its central region. Importantly, the magmatic evolution of lopolith-like basic-intermediate intrusions may open the way for extensive differentiation processes, with strong implications to petrology and metallogenesis.
\end{abstract}

KEYWORDS: Limeira intrusion; Intrusion geometry; 2D magnetometric modeling; Lopolith; Paraná Magmatic Province.

\section{INTRODUCTION}

The formation and geometry of igneous intrusions in the crust are still a subject of debate in the literature due to their diverse forms of occurrence and to a great amount of tectonic environments in which they occur. However, recently, the formation and growth of igneous intrusions have been associated to the amalgamation of several tabular-like intrusions (Cruden 1998, Menand 2011). The simplicity, larger distribution and relatively small volumes, as compared with batholiths, turn tabular intrusions an object of preferential study when dealing with igneous bodies emplacement and thermal evolution.
Geophysical modeling is an important tool, which allows defining the geometry of several geologic occurrences. The magnetometric method, despite being a relatively more complex potential one, is a very efficient technique in the detection of geological occurrences with high magnetic susceptibility contrast in relation to their environments (e.g., Kearey \& Brooks 2002).

The magnetization intensity of a rock strongly depends on the modal volume and magnetic characteristics of its minerals. For instance, magnetic anomalies produced by a $200 \mathrm{~m}^{3}$ body can be the same as those produced by a $2 \mathrm{~km}^{3}$ body, depending on its overall magnetic mineral content, while gravity anomalies are just related to density. This difference

${ }^{1}$ Instituto de Geociências, Universidade de São Paulo - USP, São Paulo (SP), Brazil. E-mail: lucas.martins.santos@usp.br,franciscocavallaro@usp.br, srfvlah@usp.br, daniel.coelho@usp.br

${ }^{2}$ Departamento de Engenharia Civil, Universidade de São Paulo - USP, São Paulo (SP), Brazil.

*Corresponding author.

Manuscript ID: 20170099. Received on: 07/18/2017. Approved on: 12/02/2017. 
may lead to misinterpretation when dealing with magnetic anomalies; however, there are ways to circumvent this problem, based on well-designed previous geological models and the knowledge of the targets magnetic properties.

The continental crust presents internal stratification associated with variations of the constituting rocks physical properties, as so far indicated by geophysical data and theoretical models based on indirect observations. As well known, the crust is constituted, at least, by two main layers, a deep one composed of mafic rocks (lower crust), and a shallow one of granitic composition (upper crust) (e.g., Rudnick \& Fountain 1995). This type of stratification could not be explained by considering only the emplacement of vertical intrusions. In fact, available seismic data reveal the occurrence of intrusive complexes made up of tabular intrusions at the base of the continental crust, which could be likely mechanisms for the formation of different crustal layers (Franke 1992).

The present work aims to provide geological and geophysical information about the geometry of Limeira Intrusion, a tabular-like occurrence related to the Mesozoic Paraná Magmatic Province (PMP), in southern Brazil. Although the province has been extensively studied concerning its stratigraphy, petrography, elemental and isotope geochemistry, and geochronology (e.g., Bellieni et al. 1984, Ernesto \& Pacca 1988, Piccirillo \& Melfi 1988, Peate 1997, Gallagher \& Hawkesworth 1994, Nardy et al. 2003, and references therein), which allowed to draw several petrogenetic and tectonic models (e.g., Peate et al. 1992, Turner \& Hawkesworth 1995, Peate \& Hawkesworth 1996, Peate 1997), there is still few detailed geological and stratigraphic research emphasizing the physical and geometric aspects of individual intrusions or lava flows.

Previous semi-detailed geophysical studies by Seixas et al. (2015) showed that the Limeira Intrusion has a more limited lateral spreading than previously considered. In addition, previous geological studies give some support for a lopolithic-like intrusion form (e.g., Lino 2015). Herein we present the results obtained through a more detailed ground magnetometric survey, coupled with geological and rock magnetic susceptibility data.

\section{GEOLOGICAL FRAMEWORK}

The PMP, southern Brazil, represents the most important Mesozoic continental flood basalt expression, constituting the Serra Geral Formation, one of the uppermost formations of the Paraná Basin (Bryan \& Ernst 2008, Milani 2004). Over $562,000 \mathrm{~km}^{3}$ of lavas (Frank et al. 2009) were erupted in a time span between $c a .133$ and $119 \mathrm{Ma}$ (Brückmann et al. 2014).
The majority of lavas are tholeiitic basalts, associated with minor andesites, riodacites and rhyolites, these later representing only ca. 3\% of the lava flows and occurring mainly in the southern Paraná Basin area (Comin-Chiaramonti et al. 1988, Nardy et al. 2002). These lava flows comprise low-Ti geochemical types, which crop out in the base, while high-Ti varieties appear at the intermediate and the uppermost levels of lava sequences (Peate et al. 1992).

The origin of the PMP is certainly related to the opening of the South Atlantic Ocean, through the process of lithospheric mantle melting under the influence of the Tristan da Cunha Plume (Peate et al. 1990, 1999, Hawkesworth et al. 1992, Turner \& Hawkesworth 1995, Marques et al. 1999) or, alternatively, to heat accumulation under the Pangea Supercontinent (Hartmann 2014).

In the eastern area of the São Paulo State, the high-Ti PMP magmatism is characterized by tabular-shaped intrusions, such as dikes, sills, and laccoliths (Zalán et al. 1986). Most dikes intrude basement rocks and form expressive dike swarms (Peate et al. 1992) while the emplacement of sub-horizontal tabular intrusions occur mainly in sedimentary host discontinuities; estimated total thickness of such intrusions vary in general between 2 to $200 \mathrm{~m}$, but may reach up to $1,000 \mathrm{~m}$ (Marques \& Ernesto 2004).

\section{Limeira Intrusion}

The Limeira Intrusion is one among several PMP intrusions that crop out in the Sáo Paulo State central-eastern area (Fig. 1). It intrudes Permo-Carboniferous sedimentary rocks, mainly sandstones and rhythmic siltstones, of the Itararé Subgroup (Faria 2008, Lino 2015). The best freshrock expositions are found in the so-called Cavinatto, owner's family name, and Basalto 4 quarries. Soares (1985) were the first to recognize a huge intrusion at this region, named as the Limeira-Cosmópolis Sill. According to him, it would correspond to a tabular shaped intrusion, with almost $60 \mathrm{~km}$ of horizontal extension and $280 \mathrm{~m}$ of thickness, as suggested from surface evidences and available drill holes.

Several recent works, emphasizing petrological, geochemical, stratigraphical and geophysical aspects, were conducted by Faria (2008), Oliveira \& Dantas (2008), Lino (2015) and Seixas et al. (2015), among others, and highlighted some features relatively uncommon to other intrusion analogs. One of us, Silvio R. F. Vlach, had pointed out the occurrence of typical stratiform-like rocks at the medium-to deep-outcrops at the Cavinatto quarry, given by modal and textural centimetric- to decimetric-thick igneous layering.

The Limeira rock types include since aphanitic basalts and diabases, at the intrusion borders, coarse-grained monzodioritic to very coarse-grained quartz-monzodioritic rocks, inwards. Rhyolites/rhyodacites occur as late dikes, with 
$\mathrm{mm}$ - to cm-sized thickness, cutting across monzodiorites and diabases, and as $\mathrm{cm}$-sized ocelli in the upper diabases.

The main rocks are composed of plagioclase $\left(\mathrm{An}_{65-30}\right)$, clinopyroxene (augite and pigeonite), Fe-Ti oxides (ilmenite, magnetite), and some sulfides. Apatite is the main accessory mineral. Well-developed granophyric intergrowths, composed by alkali-feldspar and quartz, are typical in the coarse-grained rocks mesostasis, amounting up to $23 \%$ vol. Hydrothermal processes are evidenced by apophyllite-bearing late veins, interstitial low-temperature minerals precipitation, and substitution reactions affecting the primary mineral phases (Faria 2008, Lino 2015).

Both Faria (2008) and Oliveira \& Dantas (2008) noted the intrusion's bottom edge exposed at the Basalto 4 quarry site, and proposed that it becomes thinner to southeast. Based on ground magnetometric survey and analytical signal amplitude profiles, Seixas et al. (2015) suggest that there are two independent intrusions in the Limeira area rather than a single sill: the first corresponds to the Limeira Intrusion itself, while the second (exposed at the Sertãozinho quarry) is another intrusion located in the southern area of Limeira city.

\section{DATA ACQUISITION AND TREATMENT}

Total magnetic field (TMF) measurements were performed with two Proton Precession Overhauser

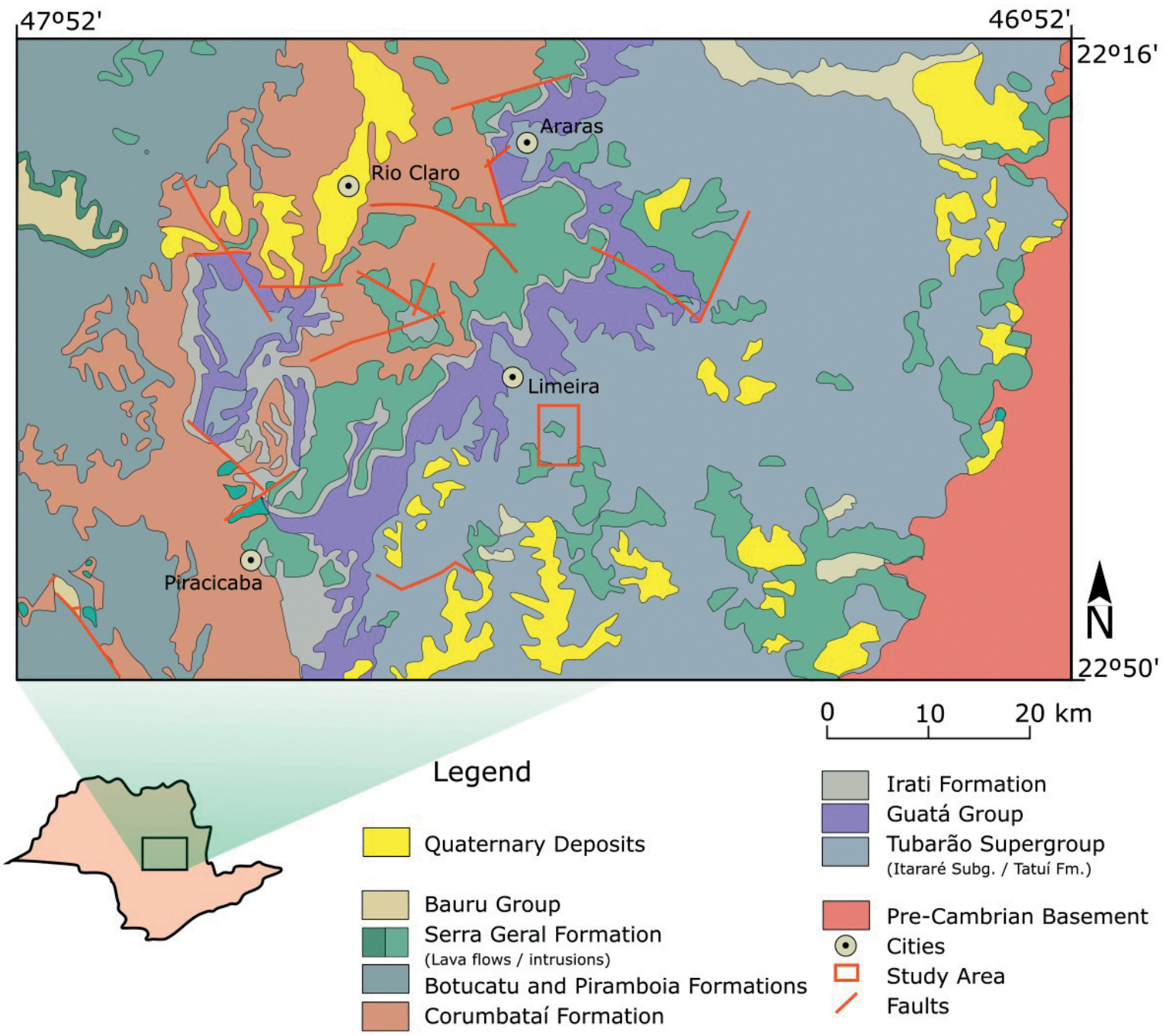

Figure 1. Geological map of central-eastern São Paulo state (Brazil), showing Paraná Basin stratigraphic Units, the pre-Cambrian basement and location of the study area. Rocks of the Tubarão Supergroup (Itararé Subgroup) constitute most of the country rocks for the intrusions related to PMP magmatism. Simplified from Perrota \& Salvador (2005). 
Magnetometers (Gem System, models GSM-19), with coupled high-precision GPS systems, in 516 field stations. One of them was used for diurnal variation measurements on a fixed station far from potential anthropogenic influence, while the other was used as the rover station. The average distance between two successive measurement stations was about $30 \mathrm{~m}$ (Fig. 2).

Magnetic susceptibility (MS) data were obtained for 57 rock samples. The measurements were made on regular surfaces or slices of fresh hand samples with portable equipment from GF Instruments. On the average, ten measurements were taken on each sample. In the studied rocks,

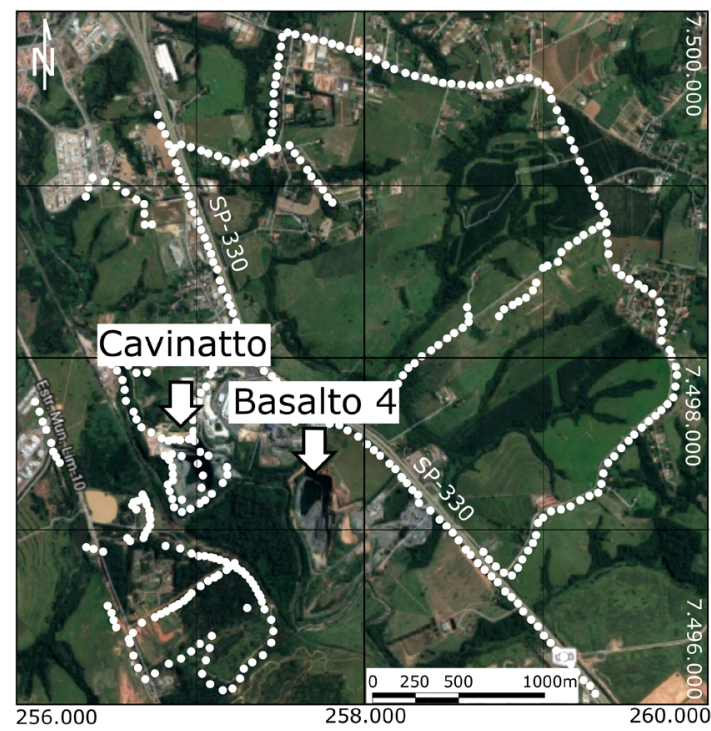

Figure 2. Image from Google Earth (accessed in May 2017) of the studied area. White arrows indicate the localization of Cavinatto and Basalto 4 quarries, spaced about $800 \mathrm{~m}$. Dotted lines represent measurement stations, and SP-330 is the Anhanguera Highway. the MS values are directly correlated with the magnetite/ Ti-magnetite modal content.

Data processing and treatment procedures are summarized in Figure 3 (see also Cavallaro 2013, Milsom 2003). The TMF values, registered on the base and rover stations, were imported into the Geosoft's Oasis Montaj ${ }^{\oplus}$ software and corrected for the diurnal magnetic variations and the International Geomagnetic Reference Field - IGRF (http:// www.ngdc.noaa.gov/seg/geomag/jsp/IGRF.jsp, accessed in May 2017).

The final processing steps included data interpolation by the minimum curvature (MC) method (Briggs 1974), analytical signal amplitude (ASA) filtering and the reduction to pole (RTP) systematics. The RTP systematics followed suggestions set out by Philips (2007), considering the frequency domain, to highlight the main features and generate geophysical maps. The available aeromagnetometric data (CPRM, Rio-São Paulo Project 1,039, carried out 150 m high) was similarly treated in order to provide a comparison and better interpretation.

The ASA filter may be used to detect the main edges and geometric features of geological occurrences with significant magnetic contrast (e.g., Nabighian 1972). With this procedure, the horizontal and vertical gradients of the detected anomalous potential field normally form a maximum and minimum pair of analytical signals; the former depicts the edges, while the later highlights the center of the involved occurrences (Nabighian 1984).

In the case of 3D analysis, the ASA filter - which represents a horizontal plane - depends on the inclination and declination directions of the target's magnetization and the geomagnetic field; therefore the filter can be applied for edge estimation under some specific conditions (Li 2006). In this way, the ASA maximum are located over the causative body's edge only when it occurs at shallow deeps, and can

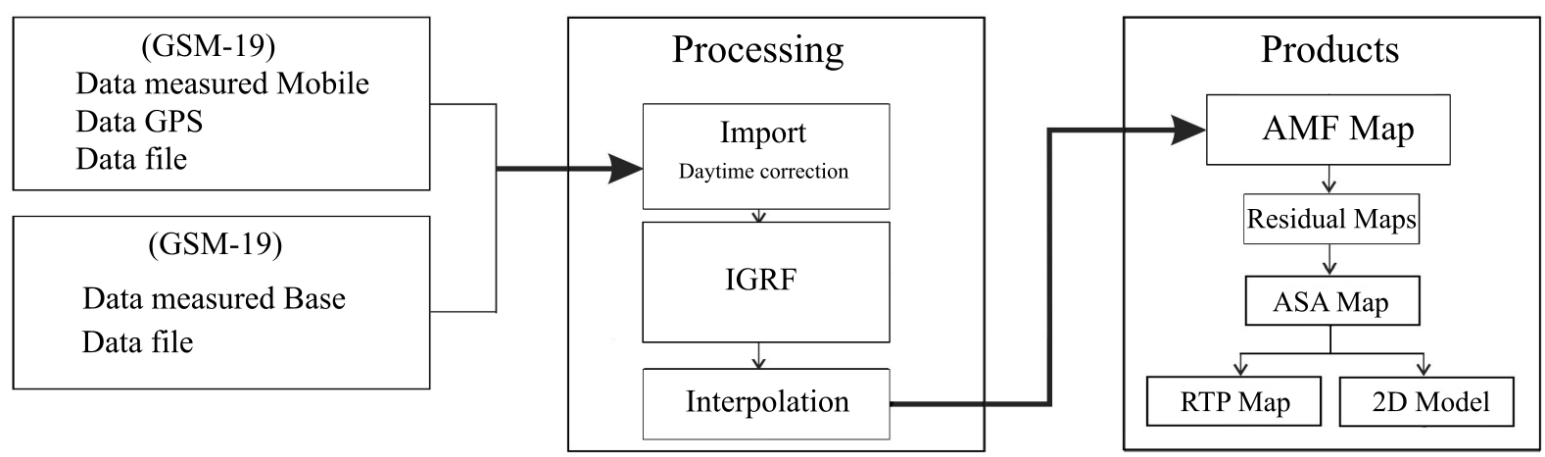

IGRF: International Geomagnetic Reference Field; RTP: reduction to pole; AMF: Anomalous Magnetic Field; ASA: Analytical signal Amplitude.

Figure 3. Illustrative flowchart depicting the main magnetometric data acquisition and processing steps, followed in this work. See text for more details. 
migrate with increasing depths to the center of the targets. According to the author, ASA filter works well for edge-detection, considering a prismatic model, when the ratio between the body top depth and its width is less than 0.1.

Based on synthetics models, Ferreira et al. (2013) have shown that the ASA filter effectively depicts up the edges of geological occurrences with a constant thickness. The authors have also demonstrated different methods for edge detection, based mainly on directional derivatives.

The RTP systematics (Baranov 1957) was applied to recalculate data intensity, as well as to transpose the magnetic anomalous field (MAF) onto the geomagnetic pole reference, where the induced magnetization is in the vertical position. If the total magnetization direction is known (Kearey \& Brooks 2002), it turns the induction polarization independent of the direction of the geomagnetic field (Telford $e t$ al. 1976), by transforming the dipolar anomaly into a monopolar one (e.g., Baronov 1957, Nabighian 1972, 1984).

The remnant magnetization affects the interpretation of magnetic anomalies and generates misinterpretation concerning targets shape and size (e.g., Cordani \& Shukowsky 2009). The South Atlantic Anomaly (Hartmann \& Pacca 2009), characterized by low magnetic intensities in southern America, results in a natural remnant magnetization more important than the induced one. Thus, the theoretical response may be not compatible with the observed anomaly. The available paleomagnetic data (Ernesto et al. 1999) was used to correct, through conventional vectorial sum, the inclination and declination directions of the total magnetization. The reference values used, as well as the resulting total magnetization vector, are summarized in Table 1.

2-D forward magnetic modeling was conducted from total anomaly profiles, exported from Geosoft, using the GRAVMAG software (Pedley et al. 1997). This software allows construct polygons with different forms and magnetic susceptibilities using measured data profiles to create a theoretical anomaly, which could be successively refined to a best possible solution. In this sense, a previous good geological framework is necessary to build any magnetic coherent models (Pedley et al. 1997).

Table 1. Reference values for inclination and declination of the induced and remnant magnetization vectors, and the resulting computed total magnetization vector.

\begin{tabular}{l|c|c}
\hline $\begin{array}{l}\text { Magnetization } \\
\text { direction }\end{array}$ & Inclination $\left({ }^{\circ}\right)$ & Declination $\left({ }^{\circ} \mathbf{A z}\right)$ \\
\hline Induced & -35.89 & -21.08 \\
\hline $\begin{array}{l}\text { Remnant (Ernesto } \\
\text { et al. 1999) }\end{array}$ & -34.30 & 354.70 \\
\hline Resulting & -35.30 & -13.10 \\
\hline
\end{tabular}

\section{RESULTS AND DISCUSSION}

\section{The geologic suggested model}

The Cavinatto quarry present the best exposition of the Limeira Intrusion, currently exposing a vertical section with $c a .110 \mathrm{~m}$ deep in its southern and $c a .90 \mathrm{~m}$ in the northern sides. The intrusion has a sub-horizontal roof, which becomes stepped towards the NW area. The exposed basic-intermediate rocks show a great diversity of structures, textures, and modal compositions. The most typical types may be grouped in aphanitic basalts, diabases, monzodiorites and quartz-monzodiorites. Petrographic and geochemical details of the main rock types, as well as chemical compositions of the rock-forming minerals details, can be found in Faria (2008) and Lino (2015). A brief general characterization is presented in the following.

The aphanitic varieties (1.0-1.3 m thick) probably accompany all intrusion contours. They are made of massive thin chilled margins in contact with thermally metamorphosed sedimentary rocks, and aphanitic basic rocks, which may show some hydrothermal alteration due to interaction with the $\mathrm{H}_{2} \mathrm{O}$-bearing host rocks. As granulation increases progressively inwards, the rock became a diabase, with a phaneritic texture and structures that changes from amygdaloidal to massive inwards. The later crops out from $c a$. 1.3 to $20 \mathrm{~m}$ deep.

Clinopyroxene monzodiorites occur from ca. 20 to $60 \mathrm{~m}$ deep; their contacts with the overlaying diabases are usually sharp. They are very heterogeneous coarse-grained rocks, sometimes with a "jaguar-skin" aspect given by the irregular distribution of the mafic and felsic minerals. Felsic pods do contain typical granophyric intergrowths. Granulation increases downwards while the mafic content decreases.

Clinopyroxene quartz-monzodiorites occur from ca. 60 to $90 \mathrm{~m}$ deep; they are heterogeneous coarse- to very coarsegrained rocks with $\mathrm{cm}$-sized thin prismatic crystal of pyroxene, and well developed - sometimes platy - magnetite crystals, which imprints a grid-like texture over a similar "jaguar-skin" aspect. Their contacts with the monzodiorites appear to be gradational.

To the deepest levels exposed within the quarry, rock granulation decreases and compositions become again monzodioritic. These rocks are the ones characterized by rhythmic relatively mafic- and felsic-rich layers with sub-horizontal dips. Importantly, they occur only on the eastern and southern quarry walls.

The average SM values obtained for these rocks are presented in Table 2 . The basic-intermediate rocks present an average value about $44.5 \times 10^{-3}(\mathrm{SI})$, while the sedimentary host rocks show, as expected, a much lower one, about $0.219 \times 10^{-3}(\mathrm{SI})$. Among the formers, the aphanitic basalts, the monzodiorites, and the quartz-monzodiorites 
present also very contrasted averages values (from 80 to -45 and $25 \times 10^{-3} \mathrm{SI}$, respectively), in accordance with their Ti-magnetite/magnetite modal contents.

The following field observations suggest a lopolith- rather than sill- or laccolith-like intrusion geometry as presented in Figure 4 (see also Lino 2015):

- part of northern contact with the enclosing siltstones is sub-vertical down to, as least 30-40 m deep, as revealed by prospecting drill holes in country rocks.;

- structural emplacement evidences observed along the intrusion suggest it thins towards northwest, east and southeast;

the exposed layered sequences did not present the expected lateral distribution. They appear to constitute more or less concentric, localized, layers.

\section{Geophysical analysis}

Geophysical results are presented as magnetic anomaly maps for ground and aerial surveys, and the final 2D forward modeling, as follows.

\section{Magnetic anomaly maps}

The total magnetic anomaly maps are presented in Figure 5. They show similar positive and negative anomalies, as expected for targets located at this magnetic latitude - with predominant induced magnetization — pointing to a dipole over the Cavinatto and Basalto 4 quarries, which defines the probable horizontal occurrence of the intrusion. The main observed differences between the ground- and aerial-based maps are the dipole lay out, reflecting contrasted data acquisition systematics, and the anomalies intensities, which result from distinct vertical distances between the measurements and the target in each case.

The derived ASA maps are depicted in Figure 6. Of note, its application is valid in our case, with a favorable ratio between top depth ( $-20 \mathrm{~m}$, based on field observations) and the expected width of Limeira Intrusion $(>1,000 \mathrm{~m}$, based on quarries location). So the use of both ground-and aerial-based maps, with different data distribution, allows to better delimit the possible limits of the intrusion. The terrestrial data presents better resolution and maximum ASA

Table 2. Magnetic susceptibility $\left(\times 10^{-3} \mathrm{SI}\right.$ ) and average modal composition of opaque phases (mainly Ti-magnetite/ magnetite and ilmenite) within the measured samples for the main rock types exposed in the Limeira Intrusion.

\begin{tabular}{l|c|c|c|c|c|c}
\hline Rock type & $\begin{array}{c}\text { Chilled } \\
\text { margin }\end{array}$ & Diabase & $\begin{array}{c}\text { Monzodiorite } \\
\text { (uppermost) }\end{array}$ & $\begin{array}{c}\text { Monzodiorite } \\
\text { (lowermost) }\end{array}$ & $\begin{array}{c}\text { Quartz- } \\
\text { Monzodiorite }\end{array}$ & $\begin{array}{c}\text { Host } \\
\text { Rocks }\end{array}$ \\
\hline $\begin{array}{l}\text { Average } \\
\text { susceptibility } \\
\text { (SI x 10-3) }\end{array}$ & 80 & 65 & 50 & 38 & 25 & 0.219 \\
\hline $\begin{array}{l}\text { \% Modal of } \\
\text { opaque phases }\end{array}$ & 20 & 15 & 7.5 & 8 & 6 & $\sim 0$ \\
\hline
\end{tabular}

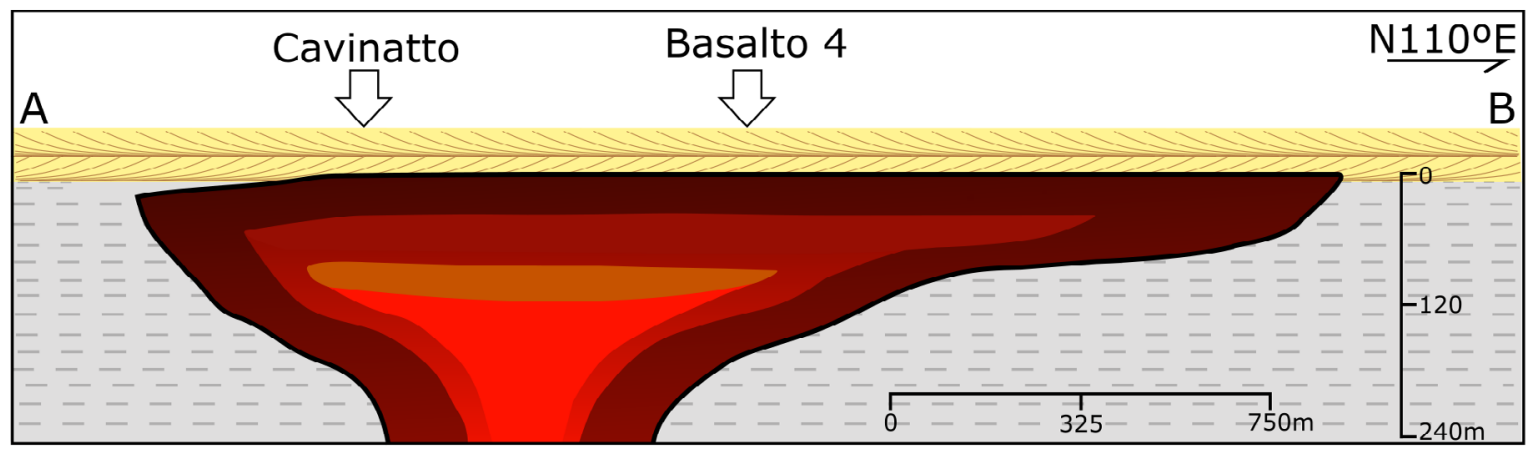

Limeira intrusion

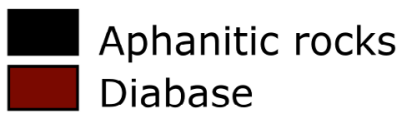

Itararé Subgroup

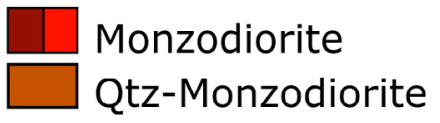

Sandstone Siltstone

Figure 4. Schematic (N110E) geological cross section through Limeira Intrusion, showing the distribution of the main rock-types, and the localization of the quarries. The figure illustrates the geometry of the intrusion based on interpretation of field observations. 

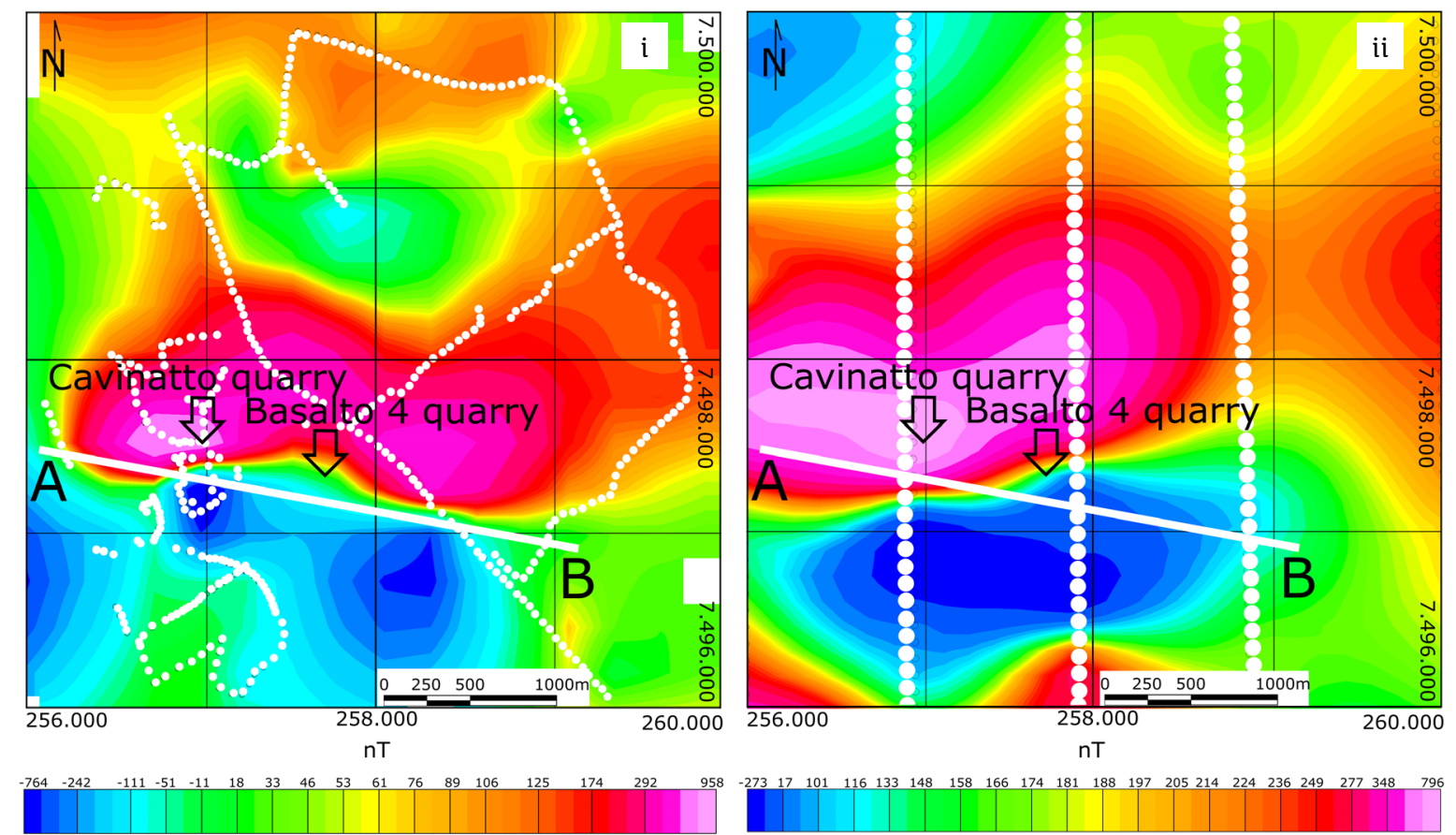

Figure 5. Total anomalous magnetic field (nT) maps for the Limeira Intrusion based on our ground survey (i) and the available aerial data (ii). The locations of the Cavinatto and Basalto 4 quarries, and the AB suggested geologic cross section (Fig. 4) are indicated. Note the dipolar anomaly centered over the quarries in both maps and the difference range between the anomalous field intensities.
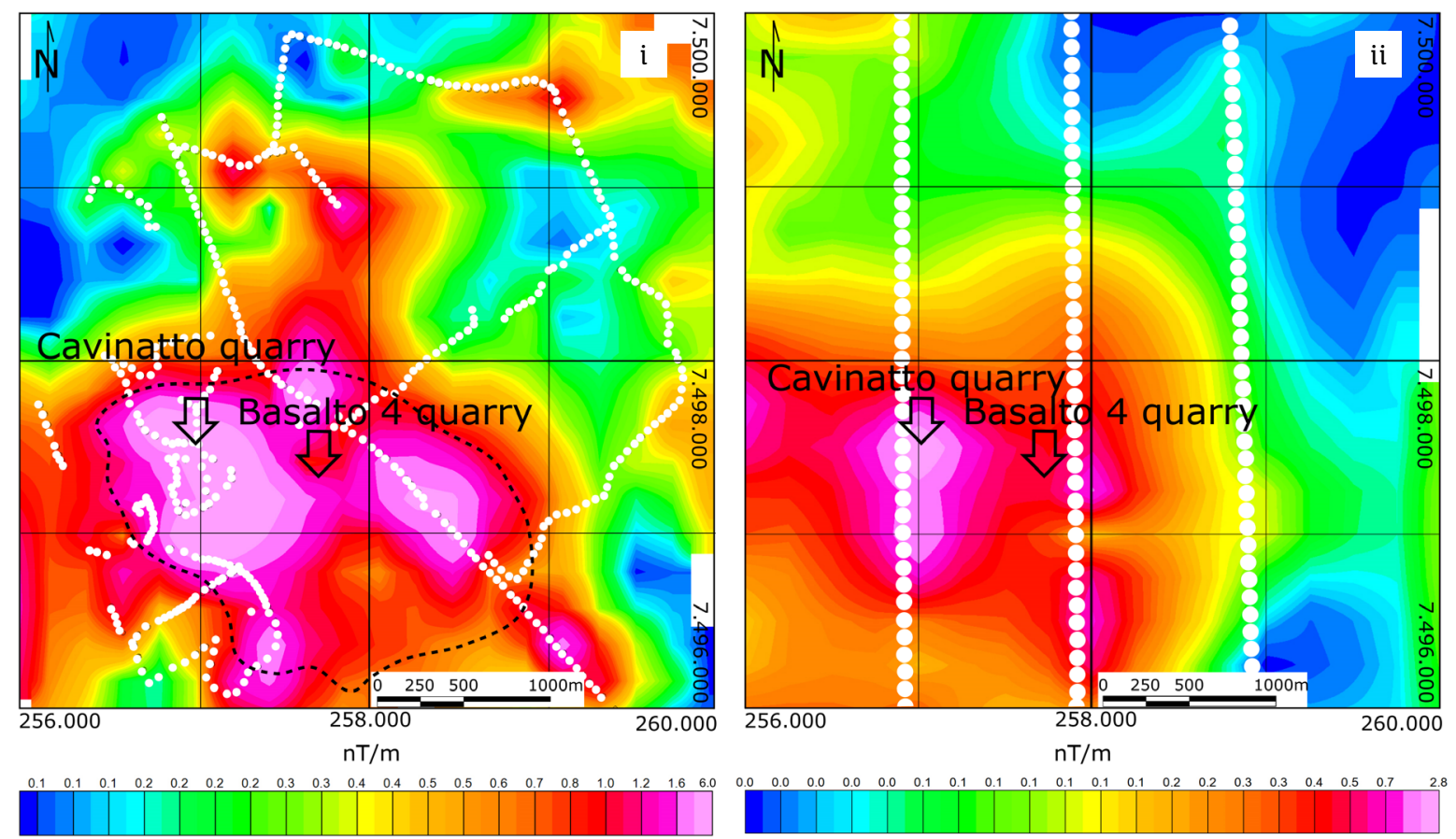

Figure 6. Analytical Signal Amplitude (ASA, nT/m) maps for the Limeira Intrusion, based on MAF data of ground survey (i) and the available aerial data (ii). Note that the ground data highlights two main regions with high ASA values, while aerial data (more defocused) presents an additional high ASA to southern, related to the raw data acquisition contrasted features (white dots). The black dotted line in (i) is our best estimated intrusion limits, based on both maps. 
values twice as high as the aerial data due to the target proximity; on the other hand, the aerial data is cleaner from possible anthropic interferences. Their combination allows to suggest the intrusion limits quite well on the basis of the maximum signal, as depicted in Figure 6.

The RTP obtained maps (Fig. 7) depict anomaly geometric features and their peek distributions, which are again similar in the ground- and aerial-based maps. In fact, they give the same response: two main high anomalies, aligned with the Cavinatto and Basalto 4 quarries tie line, and a relative low anomaly between them. These lower values reflect, most probably, the lack of data over the area in both surveys.

In both cases, the positive anomaly is restricted to the most probable intrusion location. High anomaly variation gradients are observed close to the northern intrusion limits while relatively low gradients appear towards the southern limits. At first principles, the former suggest a high dipping contact while the later suggests a gradual lateral variation of the intrusion thickness.

\section{Magnetometric forward modeling}

The RTP values derived from ground survey were used to estimate the $2 \mathrm{D}$ intrusion geometry along the three main profiles shown in Figure 7. For simplicity and easiness of data treatment, this model considers an average value for the magnetic susceptibility [44.5 $\left.\left(10^{-3} \mathrm{SI}\right)\right]$, which appears to not affect substantially the overall model. The $A B$ profile runs along the unique geological section available, while the $\mathrm{CD}$ and EF profiles run along the regions with most ground magnetometric measurements.

The presented geophysical model considers that the top depth approaches $20 \mathrm{~m}$ thickness, as estimated from measurements in some locations next to Cavinatto quarry. Results are depicted in Figure 8, which presents, among the 2D theoretical possible models, the total anomaly model that best fits with our geological data, along these profiles. In fact, as drawn in the Figure 8, calculated and observed total magnetic anomalies match very well; minor discrepancies, especially in central zone of the A-B profile, are probably related to the lack of ground measurement stations, leading to less accurate interpolation. The differences between the observed and calculated anomalies, at the beginning and ending of the CD and EF profiles, most probably, result from border effects.

\section{CONCLUDING REMARKS}

The integration of ground and aerial magnetic data, geological information and magnetic susceptibility measurements in rocks allowed set out an improved interpretation
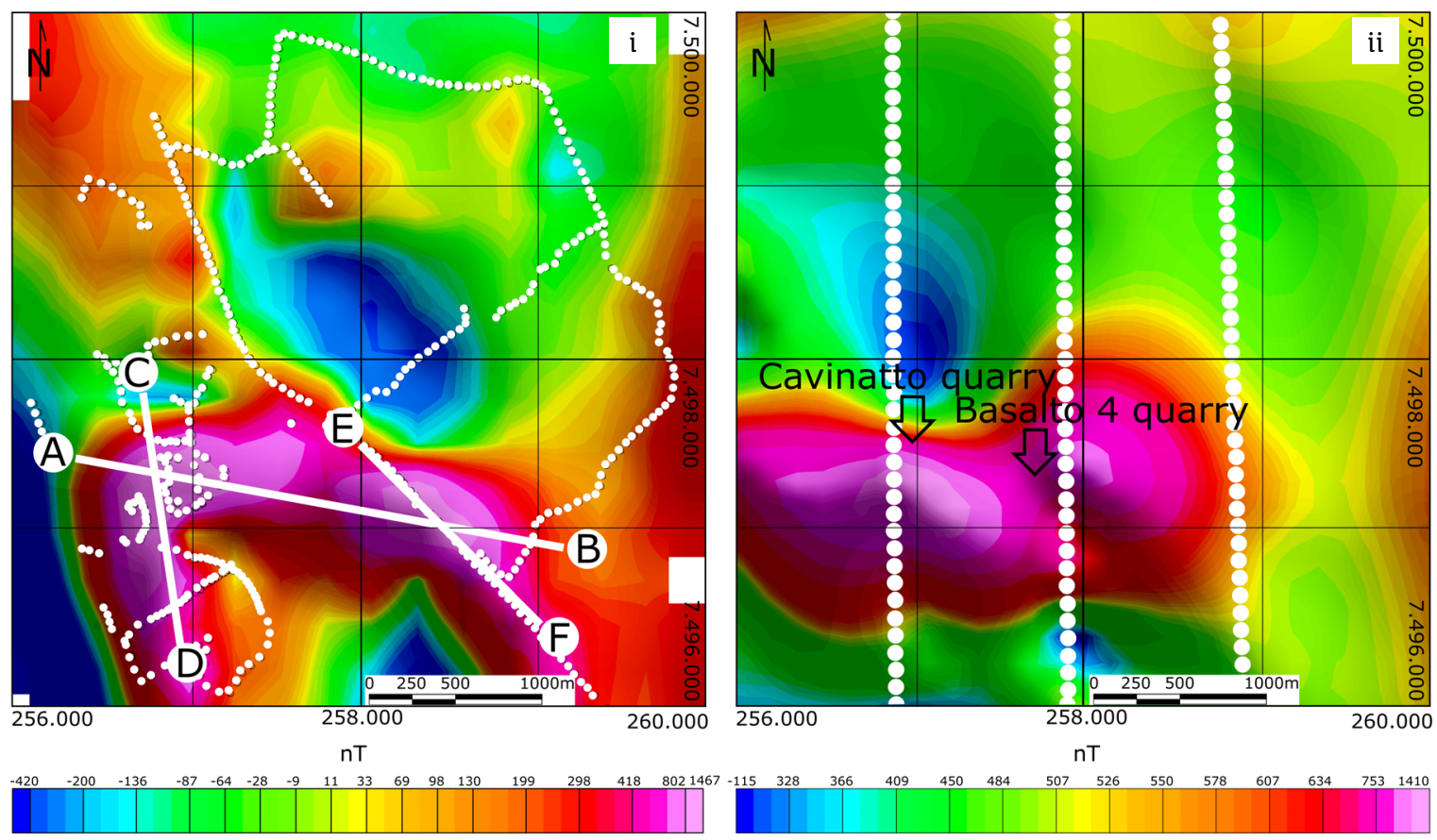

Figure 7. Reduced to Pole (RTP, in nT) maps for the Limeira Intrusion, based on MAF to ground survey (i) and available aerial data (ii). Note the high anomaly over the quarries. The $\mathrm{AB}, \mathrm{CD}$ and $\mathrm{EF}$ profiles correspond to total anomaly sections, extracted for the two-dimensional modeling. White dots represent the localization of data acquisition. 
on the lateral distribution and the 2D geometry of the Limeira Intrusion. Our results suggest that the intrusion has an elliptical shape, occupying a top area of about 2.5 to $3.0 \mathrm{~km}^{2}$, and its thickest zone corresponds to the quarries north portions. The modeled two-dimensional magnetometric profiles support a lopolithic-like intrusion geometry very well, as previously suggested from geologic evidences.

The model has some intrinsic limitations however, and the main drawback come from field station distribution, which affects interpolation processes, as some relatively large areas were not sampled due to exposure problems in relation to the location of the $\mathrm{AB}$ profile. On the other hand, the removal of the sedimentary cover, allowing direct rock exposure, increases magnetic anomalies, while the removal of rocky material - as in the extreme case of the Cavinatto quarry - decreases the total volume of ferromagnetic minerals and, thus, the magnetic signal intensity. These later effects cannot be properly quantified and corrected up to now, and may led to some misinterpretation.

The analysis of the two-dimensional profiles allows inferring some emplacement mechanisms for the Limeira Intrusion. The profiles $\mathrm{AB}$ and EF suggest that the intrusion evolved, most probably, trough progressively emplacement of fresh magmatic pulses in the central zone of the magmatic chamber, causing its growth by the mechanism of inner-accretion (e.g., Menand 2011). The north region coincides with the thicker zone of the intrusion, and supports the hypothesis that this may be the recharge area of the intrusion.

The geometry and volume of the Limeira Intrusion opened ways for the development of several specific magmatic (e.g., magmatic recharge and differentiation) and post-magmatic (e.g., hydrothermal alteration) processes,

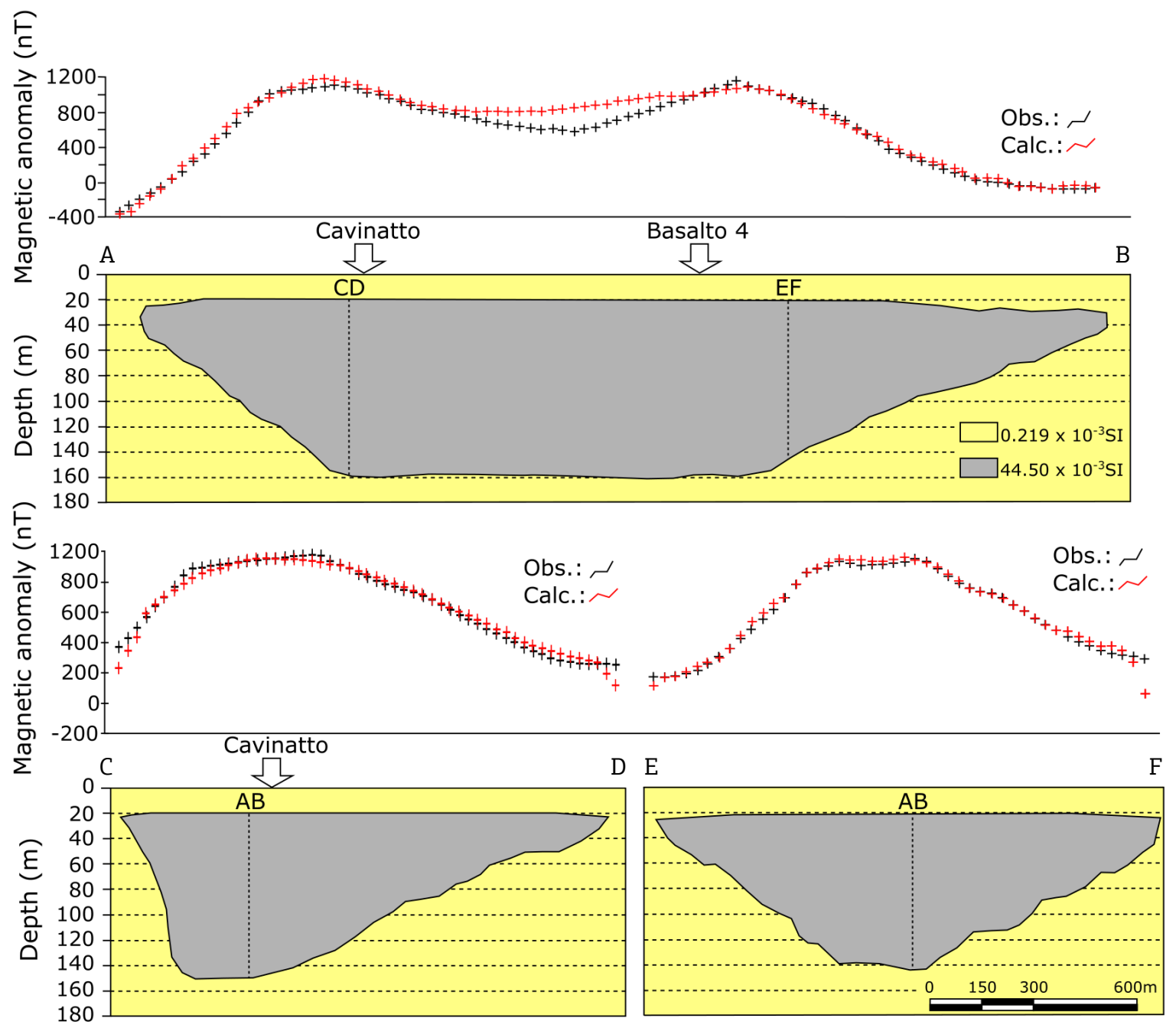

Figure 8. Schematic two-dimensional magnetic model of Limeira Intrusion, based on the presumed geologic model, total magnetic anomalies (at $\mathrm{AB}, \mathrm{CD}$ and $\mathrm{EF}$ profiles) and magnetic average susceptibility measurements. See text for discussion. 
turning it an interesting target for detailed petrological and metalogenetic studies.

\section{ACKNOWLEDGEMENTS}

We thank FAPESP Thematic Project 2012/06082-6 (Coord. Dr. E. Ruberti) for financial support. LML thanks
CAPES for a MSc. Schollarship. Previous discussions with Y. Maragoni and M. Ernesto help to improve our geophysical analysis. We are grateful to the Companhia de Pesquisa de Recursos Minerais (CPRM, Geological Survey of Brazil), which allowed the use and publication of airborne geophysical data in the region of Limeira Intrusion, and grateful to BJG editors and anonymous reviewers, who help to improve the paper.

\section{REFERENCES}

Baronov W. 1957. A new method for Interpretation of aeromagnetic Maps: Pseudo-Gravimetric Anomalies. Geophysics, 22:359-382. https://doi.org/10.1190/1.1438369

Bellieni G., Comin-Chiaramonti P., Marques L.S., Melf A.J., Piccirillo E.M., Nardy A.J.R., Roisenberg A. 1984. High-and low-TiO2 flood basalts from the Paraná plateau (Brazil): petrology and geochemical aspects bearing on their mantle origin. Neues Jahrbuch für Mineralogie Abhandlungen, 150:273-306.

Briggs I.C. 1974. Machine contouring using minimum curvature. Geophysics, 39:39-48. https://doi.org/10.1190/1.1440410

Brückmann M., Hartmann L.A., Tassinari C.C.G., Sato K., Baggio S.B. 2014. A duração do magmatismo no Grupo Serra Geral, província vulcânica Paraná. In: Hartmann L.A., Baggio S.B. (eds.), Metallogeny and mineral exploration in the Serra Geral Group. Rio Grande do Sul, UFRGS Academic Press. v. 1, p. 233-243.

Bryan S.E. \& Ernst R.E. 2008. Revised definition of large igneous provinces (LIPs). Earth-Science Reviews, 86:175-202. https://doi. org/10.1016/j.earscirev.2007.08.008

Cavallaro F.A. 2013. Investigação geofísica do alto estrutural de Anhembi - SP. PhD Thesis, Institute of Geoscience, University of São Paulo, São Paulo, 148 p. Available from: <http://www.teses.usp. br/teses/disponiveis/44/44137/tde-11022014-145456/pt-br.php>. Accessed on: April 20, 2017.

Comin-Chiaramonti P., Bellieni G., Piccrillo E.M., Melf A.J. 1988. Classification and petrography of continental stratoid volcanics and related intrusives from the Paraná basin (Brazil). In: Piccrillo E.M., Melfi A.J. (eds.), Mesozoic Flood Volcanism from the Paraná basin (Brazil): Petrogenic and Geophisical Aspects. São Paulo, IAG-USP. p. 47-72.

Cordani R. \& Shukowsky W. 2009. Magnetização Remanescente: um parâmetro crucial para a interpretação e modelamento de anomalias magnéticas em território brasileiro. Revista Brasileira de Geofísica, 27:659-667. http://dx.doi.org/10.1590/ S0102-261X2009000400009

Cruden A.R. 1998. On the emplacement of tabular granites. Journal of the Geological Society-London, 155(5):853-862. https://doi. org/10.1144/gsjgs.155.5.0853

Ernesto M. \& Pacca I.G. 1988. Paleomagnetism of the Paraná Basin Flood volcancs, Southern Brasil. In: Piccirillo E.M. \& Melf A.J. (eds.), The Mesozoic Flood Volcanism of the Paraná Basin: Petrogenetic and Geophys. Aspects. São Paulo, IAG-USP, p. 229-255.

Enesto M., Raposo M.I.B., Marques L.S., Renne P.R., Diogo L.A., De Min A. 1999. Paleomagnetism, geochemistry and $40 \mathrm{Ar} / 39 \mathrm{Ar}$ dating of the North-eastern Paraná magmatic province: tectonic implications. Journal of Geodynamics, 28:321-340. DOI: 10.1016/S0264-3707(99)00013-7

Faria C.A. 2008. Geoquímica, Petrografia e Evolução Magmática do Sill de Limeira. Dissertation, Institute of Geoscience, University of
São Paulo, São Paulo, 106 p. Available from: <http://www.teses.usp. br/teses/disponiveis/44/44143/tde-04122008-152040/en.php>. Accessed on: April 1, 2017

Ferreira F.J., de Souza J., Bongiolo A.B.S., de Castro L.G. 2013. Enhancement of the total horizontal gradient of magnetic anomalies using the tilt angle. Geophysics, 78(3):J33-J41. https://doi. org/10.1190/geo2011-0441.1

Frank H.T., Gomes M.E.B., Formoso M.L.L. 2009. Review of the areal extent and the volume of Serra Geral Formation, Paraná Basin, South America. Pesquisas em Geociências, 36:49-57.

Franke W. 1992. Phanerozoic structures and events in Central Europe. In: Blundell D., Freeman R., Mueller S. (eds.), A continent revealed: the European Geotraverse. Cambridge, Cambridge University Press, p. 164-179.

Gallagher K. \& Hawkesworth C. 1994. Mantle plumes, continental magmatism and asymmetry in the South Atlantic. Earth and Planetary Science Letters, 123:105-117. https:/doi. org/10.1016/0012-821X(94)90261-5

Hartmann G.A. \& Pacca I.G. 2009. Time evolution of the South Atlantic Magnetic Anomaly. Anais da Academia Brasileira de Ciências, 81:243-255. http://dx.doi.org/10.1590/S0001-37652009000200010

Hartmann L.A. 2014. Introdução à histótria natural do Grupo Serra Geral. In: Hartmann L.A. \& Baggio S.B. (eds.), Metallogeny and mineral exploration in the Serra Geral Group. Rio Grande do Sul, UFRGS Academic Press. v. 1, p. 17-20.

Hawkesworth C.J., Gallagher K., Kelley S., Mantovani M., Peate D.W., Regelous M., Rogers N.W. 1992. Paraná magmatism and the opening of the South Atlantic. In: Storey B., Alabaster A., Pankhurst R. (eds.), Magmatism and the Causes of Continental Break-up. Geological Society, London, Special Publications, 68:221-240.

Kearey P. \& Brooks M. 2002. An introduction to Geophysical exploration. Boston, Blackwell Science Publisher. 296 p.

Li X. 2006. Understanding 3D analytic signal amplitude. Geophysics, 71(2):L13-L16. https://doi.org/10.1190/1.2184367

Lino L.M. 2015. A intrusão toleítica de Limeira (SP) contribuição à geologia e estratigrafia de uma intrusão acamadada. Monograph, Institute of Geoscience, University of São Paulo, São Paulo, 60 p. Available from: <http://sbg.sitepessoal.com/anais48cbg/st12/ ID5715_110844_52_A_INTRUSAO_TOLEITICA_DE_LIMEIRA.pdf>. Accessed on: April 122017.

Marques L.S., Dupré B., Piccirillo E.M. 1999. Mantle source compositions of the Paraná Magmatic Province (southern Brazil): evidence from trace element and $\mathrm{Sr}-\mathrm{Nd}-\mathrm{Pb}$ isotope geochemistry. Journal of Geodynamics, 28:439-458. https://doi. org/10.1016/S0264-3707(99)00020-4 
Marques L.S. \& Ernesto M. 2004. O magmatismo toleítico da Bacia do Paraná. In: Manteso-Neto V., Bartorelli A., Carneiro C.D.R., BritoNeves B.B. (eds.), Geologia do Continente Sul-Americano: Evolução e Obra de Fernando Marques de Almeida. São Paulo, Beca, p. 245-263.

Menand T. 2011. Physical controls and depth of emplacement of igneous bodies: a review. Tectonophysics, 500(1):11-19. https://doi. org/10.1016/j.tecto.2009.10.016

Milani E.J. 2004. Comentários sobre a origem e evolução tectônica da Bacia do Paraná. In: Mantesso-Neto V., Bartorelli A., Carneiro C.D.R. (eds.), Geologia do Continente Sul-Americano: a Evolução da Obra de Fernando Flávio Marques de Almeida. São Paulo, Beca, p. 265-291.

Milsom J. 2003. Field Geophisics. London, Jonh Wiley \& Sons Ltd., $229 \mathrm{p}$.

Nabighian M.N. 1972. The analytic signal of two dimensional magnetic bodies with polygonal crossection: Its properties and use for automated anomaly interpretation. Geophysics, 37:507-517. https://doi.org/10.1190/1.1440276

Nabighian M.N. 1984. Toward a three-dimensional automatic interpretation of potential field data via generalized Hilbert transforms: Fundamental relations. Geophysics, 49:780-786. https:// doi.org/10.1190/1.1441706

Nardy A.J.R., Oliveira M., Betancourt R., Verdugo D., Machado F.B. 2003. Litoestratigrafia da Formação Serra Geral. Geociências, 21:15-32

Nardy A.J.R., Oliveira M.A.F., Betancourt R.H.S., Verdugo D.R.H., Machado F.B. 2002. Geologia e estratigrafia da Formação Serra Geral. Revista de Geociências UNESP, 21:15-32.

Oliveira E.P. \& Dantas E. 2008. Closed System differentiation in Mesozoic High-Ti Basic Sill of Limeira, São Paulo State: Implications for the origin of bimodal felsic-mafic volcanic rocks in the Paraná Igneous Province. In: Simpósio de Vulcanismo e Ambientes Associados, 4., Foz do Iguaçu, SBG. Anais... SBG, Foz do Iguaçu.

Peate D.W. 1997. The Paraná-Etendeka Province. In: Mahoney J.J. \& Coffin M.F. (eds.), Large igneous provinces: Continental, oceanic, and planetary flood volcanism. Geophysical Monograph, Washington, D.C., p. 217-245.

Peate D.W. \& Hawkesworth C.J. 1996. Lithospheric to asthenospheric transition in Low-Ti flood basalts from southern Paraná, Brazil. Chemical Geology, 127:1-24. https://doi. org/10.1016/0009-2541(95)00086-0

Peate D.W., Hawkesworth C.J., Mantovani M.S.M. 1992. Chemical stratigraphy of the Paraná lavas (South America): classification of magma types and their spatial distribution. Bulletin of Volcanology. 55:119-139. DOI: 10.1007/BF00301125

Peate D.W., Hawkesworth C.J., Mantovani M.M., Rogers N.W., Turner S.P. 1999. Petrogenesis and stratigraphy of the high-Ti/Y Urubici magma type in the Paraná flood basalt province and implications for the nature of 'Dupal'-type mantle in the South Atlantic region. Journal of Petrology, 40(3):451-473. https://doi.org/10.1093/ petroj/40.3.451

Peate D.W., Hawkesworth C.J., Mantovani M.S.M., Shukowsky W. 1990. Mantle Plumesand flood basalts stratigraphy in the Paraná, South America. Geology, 18:1223-1226. https://doi. org/10.1130/0091-7613(1990)018\%3C1223:MPAFBS\%3E2.3.CO;2

Pedley R.C., Busby J.P., Dabek Z.K. 1997. GRAVMAG User manual interactive 2.5D gravity and magnetic modeling. British Geological Survey, Technical Report, $73 \mathrm{p}$.

Perrota M.M. \& Salvador E.D. 2005. Mapa geológico do Estado de São Paulo - Integração na escala 1:750.000. São Paulo, Programa de Levantamentos Geológicos do Brasil, CPRM.

Philips J.D. 2007. Geosoft eXecutables (GX's) developed by the U.S. Geological Survey, Version 2.0, with notes on GX development from FORTRAN code (Open-File Report 2007-1355), 111 p.

Piccirilo E.M. \& Melf A.J. (eds.). 1988. Mesozoic flood volcanism of the parana basin: Petrogenetic and Geophisical aspects. São Paulo, IAG-USP, $600 \mathrm{p}$.

Rudnick R.L. \& Fountain D.M. 1995. Nature and composition of the continental crust: a lower crustal perspective. Reviews of Geophysics, 33(3):267-309. DOI: 10.1029/95RG01302

Seixas A.R., Nardy A.J.R., Moreira C.A., Pereira A.M. 2015. Caracterização magnetométrica do Sill de Limeira-SP. Geociências, 34:169-184.

Soares P.C. 1985. Informações sobre Sills de diabásio da Bacia do Paraná. Curitiba, DOCEGEO.

Telford W.M., Geldart L.P., Sheriff R.E., Keys D.A. 1976. Applied Geophysics. Cambridge, Cambridge University Press, 860p.

Turner S.P. \& Hawkesworth C.J. 1995. The nature of the subcontinental mantle: constraints from the major element composition of continental flood basalts. Chemical Geology, 120:295-314. https:// doi.org/10.1016/0009-2541(94)00143-V

Zalán P.V., Conceição J.D.J., Wolff S., Astolf M.A.M., Vieira I.S., Neto E.V.S., Marques A. 1986. Análise da bacia do Paraná. Relatório Interno Gt-Os-009/85 (Depex-Cenpes), Rio de Janeiro, Petrobras, 195 p.

(c) 2018 Sociedade Brasileira de Geologia

This is an open access article distributed under the terms of the Creative Commons license. 